\title{
Pemberian Nutrisi Enteral kasus Bedah Anak: Pengaruh pada Status Nutrisi
}

\author{
Supriyadi Bektiwibowo, Zakiudin Munasir, Sri Sudaryati Nasar
}

Latar belakang. Malnutrisi terjadi akibat pemenuhan zat gizi yang tidak optimal. Dilaporkan keadaan malnutrisi pada sekitar 40-50\% kasus bedah dan nonbedah yang dirawat di rumah sakit. Hal yang sama dijumpai di Departemen Ilmu Kesehatan Anak RS Dr. Cipto Mangunkusumo (RSCM).

Tujuan. Mengetahui efektifitas pemberian nutrisi enteral serta respons jangka pendeknya pada anak pasca tindakan operasi yang dirawat di RSCM.

Metoda. Penelitian eksperimental dengan desain the one group pretest-posttest, pemberian nutrisi enteral selama 5 hari pasca operasi pada anak derajat sedang dengan klasifikasi ASA (The American Society of Anesthesiologists) I dan II usia 1-10 tahun di ruang rawat Bedah Anak FKUI-RSCM. Dilakukan pemeriksaan antropometri sederhana, albumin dan prealbumin serum.

Hasil. Subyek penelitian 20 orang, usia rerata 3,9 $\pm 2,2$ tahun. Nutrisi enteral yang diberikan diterima dengan baik oleh 18 dari 20 subyek dan dapat ditoleransi dengan baik oleh semua subyek. Tidak ada subyek yang mengalami penurunan berat badan. Terjadi kenaikan rerata berat badan sebesar $130 \pm 100 \mathrm{~g}$, peningkatan nilai rerata albumin sebesar $0,16 \pm 0,35 \mathrm{~g} / \mathrm{dl}$, dan peningkatan nilai rerata prealbumin sebesar $2,37 \pm 3,88$ $\mathrm{mg} / \mathrm{dl}$.

Kesimpulan. Nutrisi enteral diterima, ditoleransi, serta memberikan respons yang baik terhadap status nutrisi. Nilai prealbumin dan albumin serum meningkat pada sebagian besar subyek dan tidak terjadi penurunan berat badan.

Kata kunci: nutrisi enteral, status nutrisi, albumin, prealbumin, klasifikasi ASA

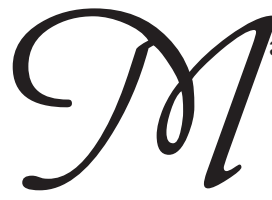

alnutrisi dapat terjadi akibat pemenuhan zat gizi yang tidak optimal. Pearce dkk, melaporkan malnutrisi pada sekitar 40-50\%

\footnotetext{
Alamat korespondensi:

Dr. Zakiudin Munasir, Sp.A(K).

Divisi Alergi Imunologi. Departemen Ilmu Kesehatan Anak FKUI RSCM, Jakarta. Jl. Salemba No. 6, Jakarta 10430.

Telepon: 021-316 1144. Fax. 021-3907743.
}

Dr. Supriyadi Bektiwibowo, PPDS Dep. Ilmu Kesehatan Anak FKUI RSCM Jakarta kasus bedah dan nonbedah yang dirawat di rumah sakit. ${ }^{1,2}$ Di Bagian Ilmu Kesehatan Anak FKUI-RSCM masalah malnutrisi terutama timbul setelah perawatan selama 14 hari. ${ }^{3}$ Hal ini menunjukkan bahwa dukungan nutrisi belum diberikan secara memadai kepada pasien dan kurangnya perhatian tenaga kesehatan terhadap perbaikan masalah nutrisi. ${ }^{4,5}$

Pada masa pasca operasi status metabolik akan meningkat $10 \%$ bila dukungan nutrisi tidak diberikan secara adekuat maka proses proteolisis otot tubuh secara berlebihan dan pada tahap lanjut akan terjadi proses katabolisme. Pengeluaran energi juga akan meningkat pada trauma operasi sebagai akibat 
respons hormonal. ${ }^{6}$ Beberapa penelitian mengenai dukungan nutrisi pada masa pasca operasi menunjukkan bahwa dukungan nutrisi yang diberikan dapat mengurangi insiden terjadinya komplikasi infeksi, mempercepat proses penyembuhan luka operasi serta memperpendek masa perawatan di rumah sakit, sehingga selain meningkatkan kualitas hidup juga dapat mengurangi beban biaya yang dihubungkan dengan lama masa perawatan dan tingkat morbiditasnya. ${ }^{7}$ Tujuan penelitian ini adalah untuk mengetahui efektifitas pemberian nutrisi enteral terhadap status nutrisi anak pasca tindakan operasi yang dirawat di RSCM.

\section{Metodologi}

Penelitian ini merupakan penelitian eksperimental. Dengan desain the one group pretest-posttest untuk mengetahui efektifitas pemberian nutrisi enteral serta respons jangka pendeknya pada kasus bedah anak di ruang rawat Bedah Anak FKUI-RSCM selama 5 hari melalui pemeriksaan status antropometri terbatas (BB), prealbumin dan albumin. Penelitian dilakukan pada bulan Januari sampai dengan Juli 2004. Kriteria inklusi yaitu kasus bedah derajat sedang dengan klasifikasi ASA I dan II, berusia 1 - 10 tahun, serta mendapatkan ijin dari orangtua. Kriteria penolakan apabila, menderita penyakit keganasan, diare, kelainan endokrin/kelainan bawaan, inborn errors of metabolism, penyakit hati ginjal kronis.

Besar sampel ditetapkan dengan menggunakan perhitungan sampel tunggal dengan uji hipótesis, sebesar 20 orang. Penilaian status nutrisi ditentukan dengan pemeriksaan antropometri terbatas yaitu berat badan (BB), kadar prealbumin dan albumin serum. Berat Badan diukur dengan timbangan elektronik Ceba ${ }^{\circledR}$, prealbumin diperiksa dengan metode radial immunodiffusion, dan albumin dengan metode bromcresol green. Nilai normal albumin ditetapkan 3 3,5 g/dl, prealbumin ${ }^{3} 15 \mathrm{mg} / \mathrm{dl}$. Pemeriksaan BB, albumin dan prealbumin dilakukan 2 kali yaitu praoperasi dan hari ke 6 setelah pemberian nutrisi enteral 5 hari pasca operasi. Nutrisi enteral yang digunakan adalah Nutren Junior ${ }^{\circledR}$, produksi PT. Nestlç Indonesia. Pada setiap pasien diberikan nutrisi enteral sesuai dengan kebutuhan kalori menurut RDA (Recommended Dietary Allowances) sesuai BB ideal menurut indeks BB/TB. Selama pemberian nutrisi enteral dilakukan pemantauan daya terima dan toleransi pasien (adanya gejala mual, muntah, kembung dan diare). Daya terima dianggap baik bila dapat menghabiskan $\geq 2 / 3$ porsi masukan nutrisi, kurang bila hanya dapat menghabiskan $<2 / 3$ porsi masukan nutrisi.

Data diolah dengan program SPSS versi 12.0, disajikan secara deskriptif dalam bentuk tabel, gambar dan tekstular.

\section{Hasil}

Jumlah subyek penelitian 20 anak terdiri dari 15 lakilaki dan 5 perempuan yang memenuhi persyaratan dan bersedia mengikuti penelitian. Usia rerata $3.9 \pm 2.2$ tahun, dengan kisaran 1-10 tahun. Diagnosis terbanyak adalah hipospadia (6 kasus), limfangioma, kontraktur dan hernia (masing-masing 2 kasus), lipoma, fraktur, cauda talipes equino vagus (CTEV), apendisitis akut, hemangioma, hidrokel, labiognatopalatoskisis dan dislokasi sendi (masing-masing 1 kasus). Pada masa preoperasi 11 dari 20 pasien memiliki status gizi kurang, selebihnya memiliki status gizi baik. Tujuh belas pasien termasuk dalam klasifikasi ASA I dan 3 pasien termasuk dalam klasifikasi ASA II (lipoma, fraktur, apendisitis).

Delapan belas dari 20 pasien dapat menerima dengan baik nutrisi enteral yang diberikan, sedangkan

Tabel 1. Status nutrisi sebelum dan sesudah pemberian nutrisi enteral selama 5 hari

\begin{tabular}{lcccc}
\hline \multirow{2}{*}{ Variabel } & & Sebelum & Sesudah & Perbedaan \\
\cline { 3 - 5 } & & Rerata \pm SD & Rerata \pm SD & Rerata \pm SD \\
\hline Berat badan $(\mathrm{Kg})$ & 20 & $13,5 \pm 4,5$ & $13,6 \pm 4,4$ & $0,13 \pm 0,1$ \\
Albumin $(\mathrm{g} / \mathrm{dl})$ & 20 & $4,0 \pm 0,4$ & $4,1 \pm 0,3$ & $0,16 \pm 0,35$ \\
Prealbumin $(\mathrm{mg} / \mathrm{dl})$ & 20 & $12,4 \pm 2,9$ & $14,8 \pm 2,8$ & $2,37 \pm 3,88$ \\
\hline
\end{tabular}


2 pasien mempunyai daya terima kurang baik. Nutrisi enteral yang diberikan dapat ditoleransi dengan baik oleh pasien lain (Tabel 1).

Setelah diberikan nutrisi enteral selama 5 hari terjadi kenaikan rerata berat badan sebesar $130 \pm 100$ g, peningkatan nilai rerata albumin sebesar $0,16 \pm 0,35$ $\mathrm{g} / \mathrm{dl}$ dan peningkatan nilai rerata prealbumin sebesar $2,37 \pm 3,88 \mathrm{mg} / \mathrm{dl}$. Setelah pemberian nutrisi enteral selama 5 hari, baik pada kelompok dengan gizi baik maupun kelompok gizi kurang dengan klasifikasi ASA I dan II tidak ada yang memperlihatkan penurunan berat badan bahkan 18 penderita mengalami peningkatan berat badan (Gambar 1).

Pada masa preoperasi, sebelum diberikan nutrisi enteral terlihat nilai prealbumin baik pada kelompok gizi baik dan gizi kurang sebagian besar di bawah nilai normal. Setelah pemberian nutrisi enteral pada masa pasca operasi terjadi peningkatan nilai prealbumin serum pada kelompok gizi baik dan kelompok gizi kurang dengan klasifikasi ASA I dan ASA II seperti yang diperlihatkan pada Gambar 2.

Nilai albumin serum pada sebagian besar pasien pada masing-masing kelompok gizi terlihat normal pada masa pra operasi. Terjadi peningkatan nilai albumin serum pada masing-masing kelompok setelah pemberian nutrisi enteral selama 5 hari, seperti yang diperlihatkan pada Gambar 3.

\section{Diskusi}

Penelitian ini memiliki beberapa keterbatasan yang berkaitan dengan masalah teknis dalam pelaksanaannya, seperti subyek yang tidak homogen, tidak ditelitinya pengaruh penyakit dan komplikasinya sebagai variabel bebas, karena perubahan status nutrisi selama perawatan selain dipengaruhi oleh pemberian nutrisi enteral juga dipengaruhi oleh kedua hal tersebut.

Nutrisi enteral yang diberikan dapat diterima dengan baik oleh sebagian besar subyek (18 dari 20 subyek), hanya 2 subyek memiliki daya terima kurang baik. Bila dihubungkan dengan klasifikasi ASA, 3 pasien dengan ASA II memiliki daya terima baik sedangkan 2 dari 17 dengan ASA I daya terimanya kurang baik. Dukungan nutrisi pada sebagian besar pasien dalam penelitian ini diberikan secara oral (18 dari 20 subyek). Pada pasien yang memiliki daya terima kurang baik pemberiannya dilakukan per sonde, dengan demikian kebutuhan zat gizi pasien dapat tetap terjamin. Walaupun nutrisi enteral memiliki bentuk penyajian yang baku dan tidak bervariasi namun nutrisi enteral memiliki keunggulan yaitu kebutuhan zat gizi dapat selalu terjamin dengan memberikannya per sonde. Dengan daya terima nutrisi enteral yang sedemikian baik maka dukungan nutrisi yang

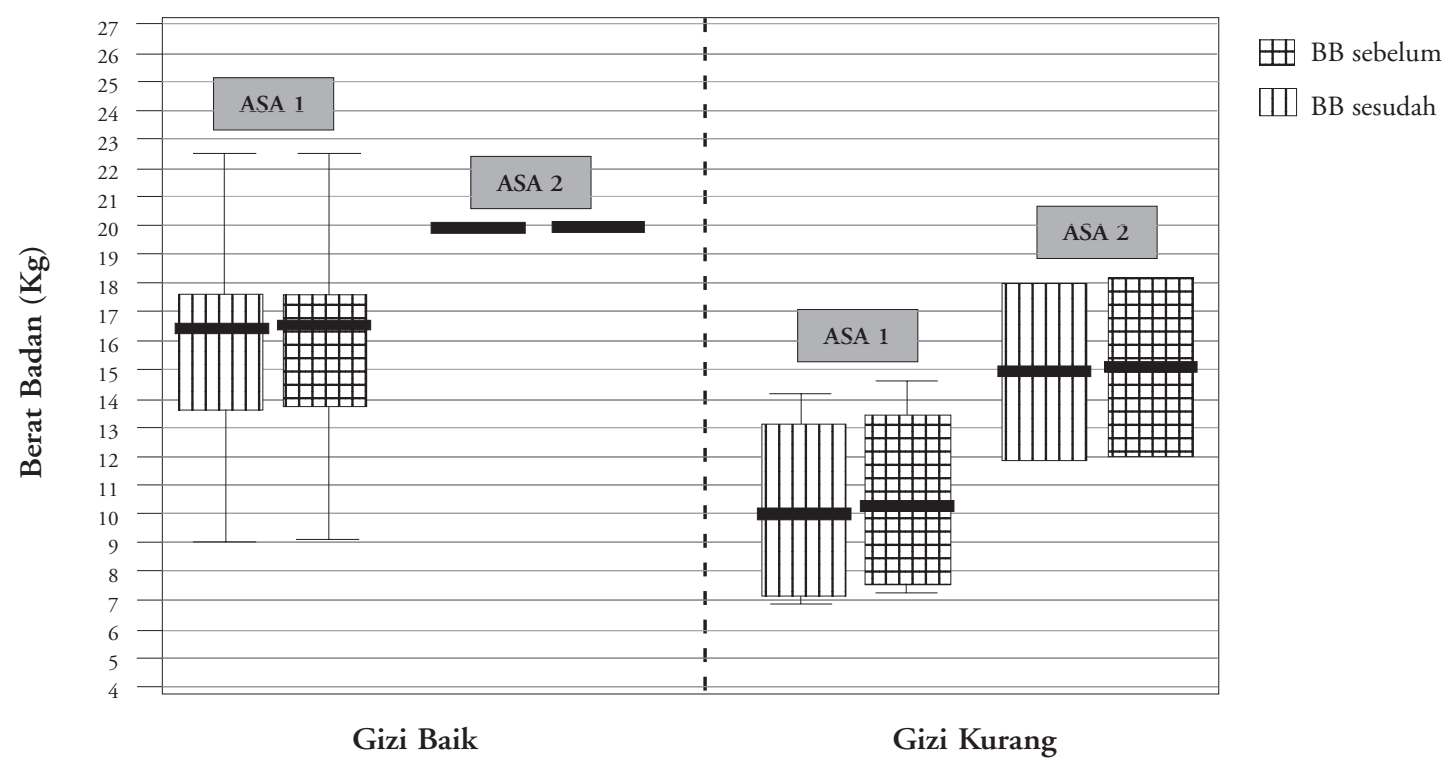

Gambar 1. Hubungan status gizi dan klasifikasi ASA dengan berat badan sebelum dan sesudah pemberian nutrisi enteral selama 5 hari. 


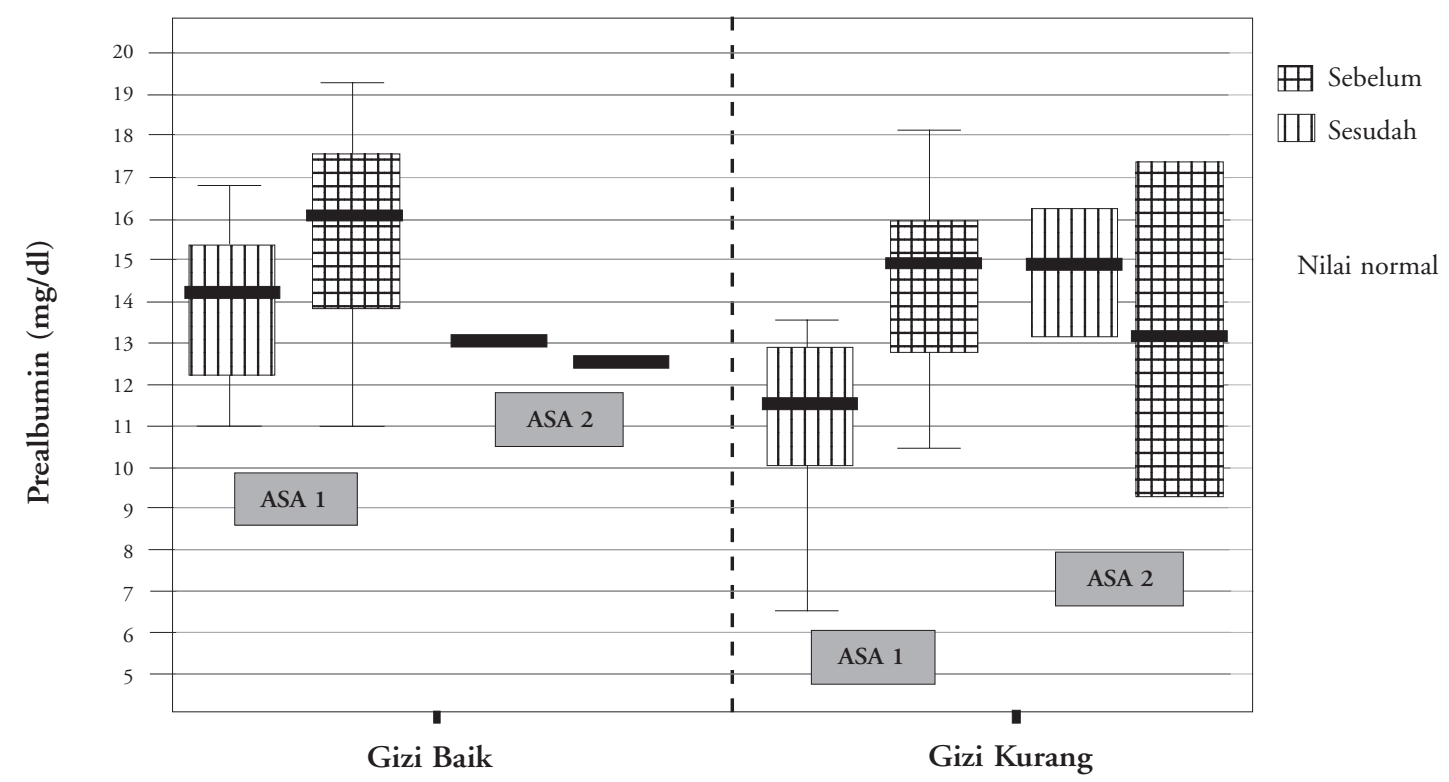

Gambar 2. Hubungan status gizi dan klasifikasi ASA dengan nilai prealbumin serum sebelum dan sesudah pemberian nutrisi enteral selama 5 hari.

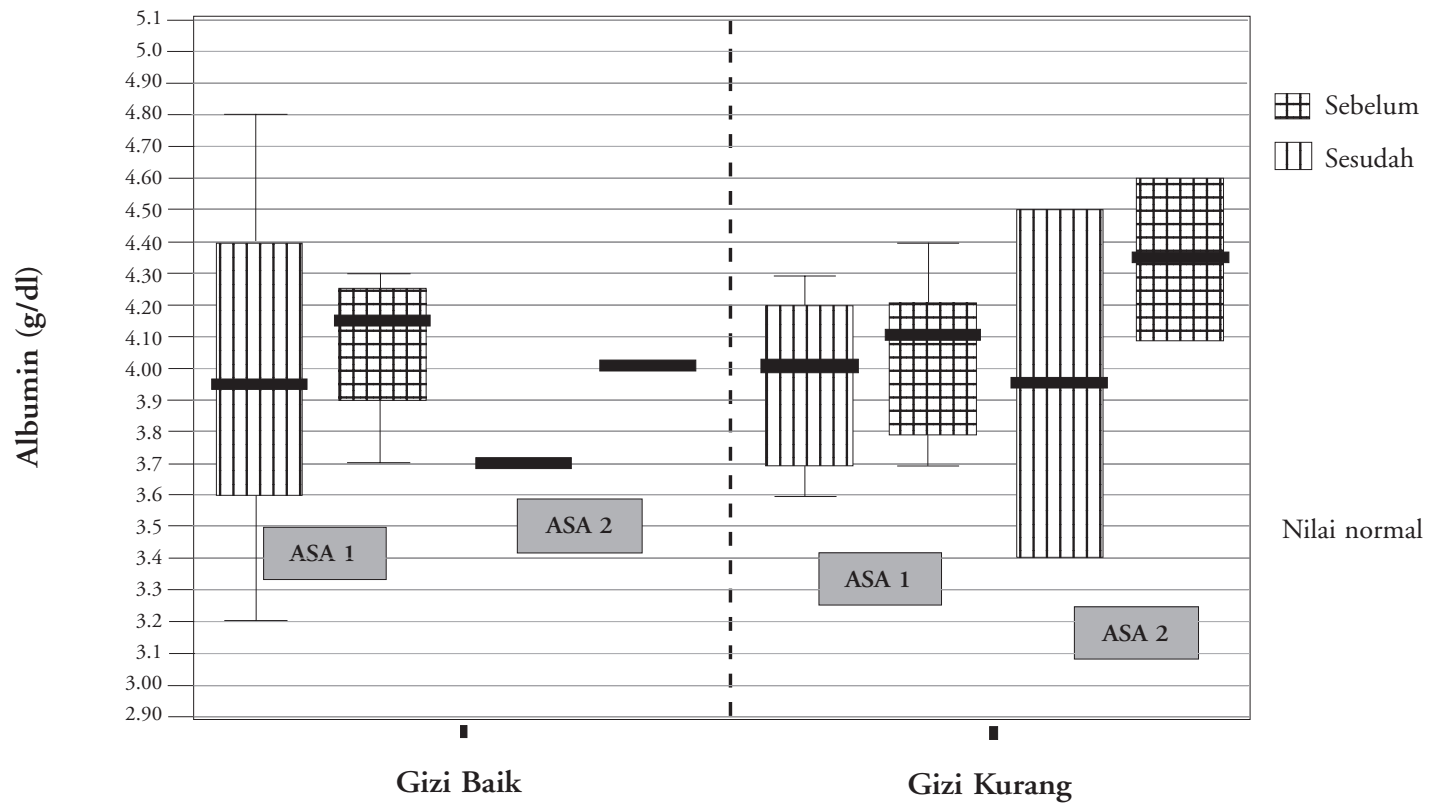

Gambar 3. Hubungan status gizi dan klasifikasi ASA dengan nilai albumin serum sebelum dan sesudah pemberian nutrisi enteral selama 5 hari.

bertujuan untuk mencapai atau paling tidak mempertahankan status nutrisi yang optimal dapat terlaksana karena makin sedikit tersisa makanan, sehingga nutrisi enteral dapat dijadikan sebagai alternatif dukungan nutrisi yang baik bagi anak.

Toleransi terhadap pemberian nutrisi enteral tergantung pada beberapa faktor, antara lain kapasitas fungsional saluran cerna, jenis formula, kecepatan pemberian, dan obat-obatan yang diberikan. Keohane dkk (1984), dalam penelitiannya mendapatkan gejala mual dan muntah terjadi pada $20 \%$ kasus yang mendapatkan nutrisi enteral, sementara Bliss dkk, 
mencatat 5-30\% kasus mengalami diare, sedangkan Cataldi-Betcher dkk, mencatat 6,2\% kasus mengalami gangguan saluran cerna seperti diare, mual dan muntah. ${ }^{8-10}$ Pada penelitian ini nutrisi enteral yang diberikan dapat ditoleransi dengan baik oleh seluruh pasien. Hal ini menunjukkan bahwa nutrisi enteral yang diberikan pada penelitian ini relatif aman untuk dikonsumsi. Adanya perbedaan mengenai gangguan toleransi nutrisi enteral terhadap saluran cerna pada penelitian ini dengan penelitian yang lainnya mungkin disebabkan oleh adanya perbedaan mengenai komposisi nutrisi enteral yang diberikan. Meskipun demikian dari beberapa penelitian yang telah dilakukan tampaknya masih terdapat kontroversi mengenai kemungkinan penyebab terjadinya gangguan toleransi saluran cerna terhadap pemberian nutrisi enteral. Moshe Shike menyatakan bahwa nutrisi enteral yang bersifat isoosmolar dapat lebih ditoleransi oleh saluran cerna dibandingkan dengan yang hiperosmolar. ${ }^{11}$ Sebaliknya menurut Keohane dkk, nutrisi enteral yang bersifat hiperosmolar ternyata tidak meningkatkan angka kejadian diare bila dibandingkan dengan yang isoosmolar, kejadian diare meningkat bermakna dengan penggunaan antibiotika berspektrum luas dalam jangka waktu yang lama. ${ }^{12}$ Meredith dkk menemukan insiden diare yang lebih rendah pada kelompok yang diberikan diet peptida dibandingkan dengan kelompok yang diberikan diet protein secara utuh. ${ }^{13}$

Menurut Cataldi-Betcher penyebab terjadinya diare dalam penelitiannya adalah multifaktorial antara lain, formula yang hiperosmolar, intoleransi laktosa dan obat-obatan yang menyertai. ${ }^{10}$ Dengan menggunakan nutrisi enteral dengan formula isoosmolar dan bebas laktosa ternyata tidak dijumpai komplikasi saluran cerna. Montejo dkk, menyimpulkan adanya korelasi antara toleransi nutrisi enteral dan berat ringannya penyakit; semakin berat kondisi penyakit maka toleransi saluran cerna terhadap nutrisi yang diberikan semakin rendah. ${ }^{14}$ Pada penelitian ini baik subyek dengan klasifikasi ASA I dan II semuanya menunjukkan toleransi yang baik terhadap nutrisi enteral. Walaupun menurut Wolters $\mathrm{dkk}$, angka morbiditas pasca operasi pada subyek dengan klasifikasi ASA II meningkat 1,5 kali bila dibandingkan dengan ASA I, ${ }^{15}$ tetapi mungkin karena pada subyek dengan klasifikasi ASA II tidak terdapat gangguan fungsional maka toleransi terhadap nutrisi enteral yang diperlihatkan tidak berbeda. Terlepas dari kontroversi yang timbul mengenai penyebab terjadinya gangguan toleransi pada saluran cerna, pada penelitian ini nutrisi enteral yang diberikan memberikan respons jangka pendek yang baik pada hampir keseluruhan subyek.

Berat badan adalah parameter pertumbuhan yang paling pengukurannya sederhana, mudah dilakukan serta merupakan indeks untuk status nutrisi sesaat. Perubahan berat badan perlu mendapat perhatian karena merupakan petunjuk adanya masalah nutrisi akut. ${ }^{16}$ Pemberian nutrisi enteral pada penelitian ini ternyata memberikan pengaruh yang nyata pada perubahan berat badan subyek, tidak ada satupun subyek yang mengalami penurunan berat badan setelah mendapatkan nutrisi enteral selama 5 hari. Hubungan status gizi dan klasifikasi ASA dengan perubahan berat badan juga menunjukkan hal yang sama, baik pada kelompok status gizi baik dengan klasifikasi ASA I dan II maupun kelompok gizi kurang dengan klasifikasi ASA I dan II tidak ada satupun yang mengalami penurunan berat badan. Secara keseluruhan terjadi peningkatan rerata berat badan sebesar $0.13 \pm 0.10 \mathrm{~kg}$ pada akhir penelitian. Meskipun kemaknaannya tidak dianalisis secara statistik, dapat dikatakan bahwa nutrisi enteral yang diberikan cenderung memberikan respons yang positif terhadap perubahan berat badan subyek. Karena pada masa pasca operasi status metabolik akan meningkat $10 \%$, bila dukungan nutrisi tidak diberikan secara adekuat maka akan menimbulkan proses proteolisis otot-otot tubuh secara berlebihan dan pada tahap lanjut akan terjadi proses katabolisme, yang akan meningkatkan kejadian malnutrisi pada masa perawatan. $^{6}$

Pemeriksaan laboratorium sebagai salah satu cara penilaian status nutrisi dapat dipergunakan baik sebagai pemeriksaan penunjang diagnosis misalnya untuk memastikan adanya defisiensi nutrien yang pada pemeriksaan klinik, antropometrik maupun dietetik masih dalam keadaan normal. Pada awal penelitian, sebelum diberikan nutrisi enteral, pada kelompok subyek yang memiliki status gizi baik ternyata sebagian besar nilai prealbuminnya di bawah nilai normal; hasil ini mengindikasikan bahwa pada subyek yang memiliki status gizi baik secara antropometris mungkin telah mengalami malnutrisi subklinis/akut secara laboratorium sehingga memerlukan intervensi dukungan nutrisi yang optimal. Sebaliknya hampir sebagian besar subyek yang memiliki status gizi yang kurang memiliki nilai albumin normal. Hal ini menunjukkan bahwa dengan waktu paruh yang lebih pendek (2-3 hari) 
prealbumin lebih sensitif dalam menilai kekurangan gizi yang terjadi secara akut dibandingkan dengan albumin yang memiliki waktu paruh lebih panjang (18-20 hari).

Pemberian nutrisi dan pemantauan status nutrisi yang terlampau singkat menjadi penyebab kurangnya respons peningkatan nilai albumin bila dibandingkan dengan peningkatan nilai prealbumin. Mengenai terjadinya penurunan nilai prealbumin yang dialami oleh seorang subyek di akhir penelitian, kemungkinan disebabkan oleh komplikasi infeksi sekunder yang terjadi pada luka bekas operasi. Dalam kepustakaan dikatakan bahwa keadaan inflamasi akan menyebabkan penurunan nilai prealbumin yang bersifat sementara. ${ }^{17}$ Temuan yang didapatkan sesuai dengan hasil penelitian yang dilakukan oleh Ogunshina dkk, de Luis dkk, Mears dan Robinson dkk yang menyatakan bahwa prealbumin memberikan banyak keuntungan medis dibandingkan dengan albumin, karena dapat mendeteksi secara dini dan lebih akurat keadaan malnutrisi akut sehingga intervensi dukungan nutrisi dapat segera dilaksanakan sebelum kondisi status nutrisi subyek mengalami penurunan. ${ }^{11,18-22}$

Pada akhirnya dapat disimpulkan bahwa nutrisi enteral yang diberikan diterima dan ditoleransi dengan baik oleh subyek. Nutrisi enteral yang diberikan pada masa pasca tindakan operasi cenderung memberikan respons yang baik terhadap perubahan status nutrisi, nilai prealbumin dan albumin serum yang cenderung meningkat pada sebagian besar subyek dan tidak terjadi penurunan berat badan.

Mengingat keterbatasan yang ada dalam penelitian ini, maka perlu dilakukan penelitian eksperimental lanjutan dengan melibatkan lebih banyak subyek dan waktu yang lebih lama mengenai pengaruh pemberian nutrisi enteral pada masa praoperasi terhadap beberapa parameter status nutrisi baik laboratorium maupun antropometris dan pengaruhnya terhadap respon jangka pendek dan jangka panjang yang meliputi nilai dukungannya terhadap proses penyembuhan penyakit dan tumbuh kembang anak. Pada subyek yang berpotensi mengalami gangguan nutrisi, prealbumin dapat dipergunakan untuk mendeteksi secara dini adanya masalah nutrisi akut/subklinis dan untuk mengevaluasi intervensi dukungan nutrisi yang telah diberikan. Nutrisi enteral merupakan alternatif dukungan nutrisi yang relatif aman pada subyek yang berpotensi mengalami gangguan nutrisi, agar dukungan nutrisi yang diberikan dapat tetap optimal.

\section{Ucapan terimakasih}

Ucapan terima kasih serta penghargaan setinggi-tingginya disampaikan kepada Amir Thayeb, Dr. SpBA selaku Kepala Subbagian Bedah Anak FKUI/RSCM, Sastiono, Dr. SpBA selaku Kepala Unit Perawatan Bedah Anak RSCM, dan PT. Nestlé Indonesia atas terlaksananya penelitian ini.

\section{Daftar Pustaka}

1. Pearce CB, Duncan HD. Enteral feeding. Nasogastric, nasojejunal, percutaneous endoscopic gastrostomy, or jejunostomy: its indications and limitations. Postgrad Med J 2002;78:198-204.

2. Beattie AH, Prach AT, Baxter JP, Pennington CR. A randomized controlled trial evaluating the use of enteral nutritional supplements postoperatively in malnourished surgical patients. Gut 2000;46:813-8.

3. Ginting RU. Perubahan status nutrisi subyek rawat inap sesudah perawatan 14 hari di Bagian Ilmu Kesehatan Anak FKUI-RSCM. Tesis Program Pendidikan Dokter Spesialis Bagian Ilmu Kesehatan Anak FKUI-RSCM 2000.

4. Roubenoff R, Roubenoff RA, Preto J. Malnutrition among hospitalized patients. Arch Intern Med 1987;147:1462-5.

5. Weinsier RL, Hunker HM, Krumdieck CL. Hospital malnutrition: a prospective evaluation of general medical patients during the course of hospitalization. Am J Clin Nutr 1979;32:418-26.

6. Thapa BR. Nutrition support in a surgical patient. Didapat dari http://www.nutritionj.com/content/2/1/18 diakses tanggal 2 Maret 2005.

7. Salvino MR, Dechicco R, Seidner D. Perioperative nutrition support: Who and how. Clev Clin J Med 2004;71:345-51.

8. Jones KW, Slocum BA, Seltzer MH. Complications occuring during enteral nutrition support: a prospective study. J Paren Enter Nutr 1983;7:546-52.

9. Bliss DZ, Guenter PA, Settle RG. Am J Clin Nutr 1992;55:753-9.

10. Cataldi-Bethcer, Seltzer M, Slocum B, Jones K. Complications occuring during enteral nutrition support: a prospective study. J Parenter Enter Nutr 1983;7:54652.

11. Silk DBA, Keohane PP, Attrill H, Love m, Frost P. Relation between osmolality of diet and gastrointestinal side effects in enteral nutrition. Br Med J 1984;288:678-80. 
12. Moshe S. Enteral feeding. Dalam: Dudek SG, penyunting. Nutrition handbook for nursing practice; Philadelphia: J.B. Lippincott Company, 1984. h. 164356.

13. Meredith JW, Ditesheim JA, Zaloga GP. Visceral protein levels in trauma patients are greater with peptide diet than with intact protein diet. J Trauma 1990;30:825-9.

14. Montejo JC. Enteral nutrition-related gastrointestinal complications in critically ill patients: a multicenter study. Crit Care Med 1999;27:1447-53.

15. Wolters U, Wolf T, Stutzer H, Schroder T. ASA clssification and perioperative variables as predictors of postoperative outcome. Br J Anaesth 1996;77:217-22.

16. Nasar SS. Pengkajian status nutrisi anak di klinik. Disampaikan pada Kongres Nasional Ilmu Kesehatan Anak X, Bukittinggi, 16-20 Juni,1996.

17. Ingenbleek Y, Van Den SHG, De Nayer P, Visscher M. Albumin, transferrin and the thyroxine-binding prealbumin/retinol-binding protein (TBPA-RBP) complex in assessment of malnutrition. Clin Chem Acta
1975;63:61-7.

18. Mears E. Outcomes of continuous process improvement of a nutritional care program incorporating serum prealbumin measurements. Nutrition 1996;12:479-84.

19. Ogunshina SO, Hussain MA. Plasma thyroxine binding prealbumin as an index of mild protein-energy malnutrition in Nigerian children. Am J Clin Nutr 1980;33:794-800.

20. Luis DA, Aller R, de Luis J, Izaola O, Romero E, Terroba MC. Clinical and biochemical characteristics of patients with home enteral nutrition in an area of Spain. Euro J Clin Nutr 2003;57:612-5.

21. Robinson M, Trujillo E, Mogensen K, Rounds J, McManus K, Jacobs DO. Improving nutritional screening of hospitalized patients: The role of prealbumin. J Parenter Enter Nutr 2003;27:389-95.

22. Bernstein LH, Leukhardt-Fairfield CJ, Pleban W, Rudolph R. Usefulness of data on albumin and prealbumin concentrations in determining effectiveness of nutritional support. Clin Chem 1989;35:271-4. 